\title{
Big Pharma: Trick or Treat for Global Health
}

\author{
Nalimov Pavel A. \\ Rudenko Dmitry Y.
}

Tyumen State University; Tyumen State Academy of World Economy, Management and Law; Tyumen, Russia

Email:drudenko@inbox.ru

\section{Skripnuk Djamilia F.}

St. Petersburg State Polytechnical University; Russia

Email: djamilyas@mail.ru

\section{Doi:10.5901/mjss.2015.v6n1p216}

\section{Abstract}

Against the background of certain progress in global health, pharmaceutical industry is becoming a vital mechanism of effective medicines production. At the same time, being a socially-oriented unit of the world economy, the pharmaceutical market at this moment is characterized by particularly high degree of commercialization. Taking this fact into account, the authors aim to search for sufficient answers to the key question - whether pharmaceutical market solves global health problems or exists for the sake of pharmaceutical companies' profits maximizing. According to the results both the fact of uneven distribution of drugs in the context of developed and developing countries and its causes were established. It is supposed that the economical policy of largest pharmaceutical manufacturers is deliberately based on keeping shipments of innovative drugs in developing countries in static regime. The main conclusion of the pharmaceutical market ineffectiveness at the present stage was obtained by a preliminary analysis of data array using IBM SPSS Statistics 19.

Keywords: global pharmaceutical market, developed countries, pharmerging countries, public health, brand drugs, generics, life expectancy at birth, poverty.

\section{Introduction}

The pharmaceutical market as a set of its enterprises and consumers is becoming one of the most important elements of the global economy's "ecosystem". Today trends of life expectancy growth and all-round formation of conditions for successful economic development depend on investment into human capital. Here we may confidently claim that the human capital is up to the health services on the one hand, and the level of its structural parts development on the other one. It means that the pharmaceutical market as a mechanism for vital medicine drugs reproduction stimulates social and economic development of any nation. Thus, the study of trends occurring in the global pharmaceutical market is the key to successful reorientation of the national pharmaceutical sector and, by and large, is a matter of national security. Now we may confirm that this study is beneficial to the health and social policy government bodies and its structural units of developing countries passing through the era of innovational transformation.

Recognizing the progress in global health made by the international community over the past 20 years (in particular, the reduction of child mortality by 2 times for the period from 2005 to 2010; reducing maternal mortality from 543.000 in 1990 to 287.000 in 2010; a 50\%-decreasing in mortality from malaria and 15\%-decreasing in mortality from HIV (IMS Healthcare, 2013), it is impossible to miss the huge pharmaceutical industry contribution. Primarily, the pharmaceutical research industry plays a unique role in the drugs and vaccines extraction needed for diseases prevention and treatment. We should realize, that the main endowment, which pharmaceutical sector brings to the public health services is providing of fundamental researches in the field of innovative therapies. Herewith, success of all the investigations is based on continuous innovation process focused both on prevention, treatment of prevalent, complex and "neglected" diseases, and medicines improvement. It means that the pharmaceutical manufacturers' activity has become an important part of the mechanism for improving the world-wide population health.

However, the ground for the study was "a pharmaceutical manufacturer phenomenon": being a part of the system focused on vital medicines reproduction, it has become a highly commercialized unit aimed at maximal profit extracting. 
So, the volume of the global pharmaceutical market at final selling prices was estimated more than US $\$ 1$ trillion and, accordingly IMS Health forecasts (leading information-analytical organization in the field of health services), it exceed US\$1.1 trillion in 2015 (IFPMA, 2013). International Federation of Pharmaceutical Manufacturers \& Associations gives its vision to the pharmaceutical market progress: its value will approximate to US\$ 1.2 trillion in 2017 Figure 1 indicates the changes in the global pharmaceutical market's volume (blue columns) and the growth rates (red curve) for the period from 2004 to 2014 (Glumskov, 2007).

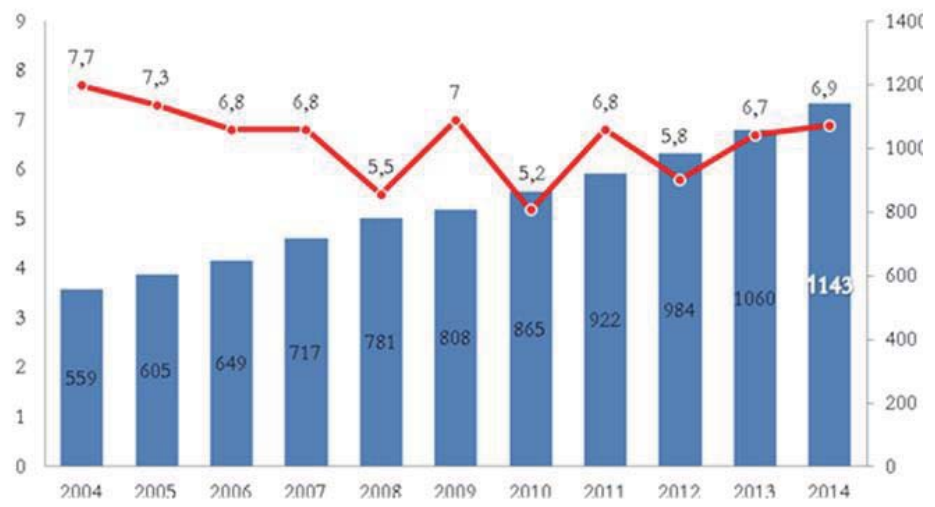

Figure 1. Global pharmaceutical market's volume and growth rates, 2004-2014

According to the global pharmaceutical market ranks $3^{\text {rd }}$ place by the market capitalization volume with the figure of US $\$ 1.431$ trillion or $5.46 \%$ after the bank (US $\$ 4.436$ trillion or $16.92 \%$ ) and energy (US $\$ 3.832$ trillion) sectors (Lin and Sokolova, 2012). At the same time it is essential to emphasize FT Global 500 ranking indicator, which illustrates the pharmaceutical market commercial nature in a more evident way (Table 1). It claims that 4 positions among the 30 largest companies in the world (13.3\%) are under the pharmaceutical giants from developed countries (named as a "Big Pharma" conglomerate (Hetman, 2003): Switzerland (Novartis, Roche) and the USA (Johnson \& Johnson, Pfizer (Financial Times, 2014).

Table 1. FT Global 500 ranking. Top 30 companies

\begin{tabular}{|c|c|c|c|c|}
\hline Ranking, 2013 & Ranking, 2012 & Company & Country of origin & Field \\
\hline 1 & 1 & Apple & USA & Electronics \\
\hline 2 & 2 & Exxon Mobil & USA & Oil \& Gas \\
\hline 3 & 13 & Berkshire Hathaway & USA & Insurance \\
\hline 4 & 3 & PetroChina & CHINA & Oil \& Gas \\
\hline 5 & 11 & Wal-Mart Stores & USA & Retail stores \\
\hline 6 & 9 & General Electric & USA & Industrial enterprises \\
\hline 7 & 4 & Microsoft & USA & Software \\
\hline 8 & 5 & IBM & USA & Software \\
\hline 9 & 12 & Nestle & SWITZERLAND & Food \\
\hline 10 & 10 & Chevron & USA & Oil \& Gas \\
\hline 11 & 6 & $\begin{array}{l}\text { Industrial \& Commercial } \\
\text { Bank of China }\end{array}$ & CHINA & Banks \\
\hline 12 & 18 & Johnson \& Johnson & USA & Pharmaceuticals \\
\hline 13 & 17 & Samsung Electronics & SOUTH KOREA & Electronics \\
\hline 14 & 8 & ChinaMobile & HONG KONG & Mobile telecommunications \\
\hline 15 & 25 & Google & USA & Software \\
\hline 16 & 16 & Procter\&Gamble & USA & Household goods \\
\hline 17 & 7 & Royal Dutch Shell & GB & Oil \& Gas \\
\hline 18 & 23 & Prfizer & USA & Pharmaceuticals \\
\hline 19 & 14 & China Construction Bank & CHINA & Banks \\
\hline 20 & 29 & Roche & SWITZERLAND & Pharmaceuticals \\
\hline 21 & 15 & AT\&T & USA & Telecommunications \\
\hline
\end{tabular}




\begin{tabular}{|lllcl|}
\hline 22 & 26 & HSBC & GB & Banks \\
23 & 19 & Wells Fargo & USA & Banks \\
24 & 28 & Novartis & SWITZERLAND & Pharmaceuticals \\
25 & 21 & JP Morgan Chase & USA & Banks \\
26 & 24 & Coca-Cola & USA & Beverages \\
27 & 30 & Toyota Motor & JAPAN & Automotive industry \\
28 & 20 & BHP Billiton & AUSTRALIA/GB & Mining \\
29 & 40 & Anheuser-Busch & BELGIUM & Beverages \\
30 & 32 & Oracle & USA & Software \\
\hline
\end{tabular}

On the one hand, all-time high revenues of pharmaceutical companies may be explained with the need to recoup huge research and development expenses (totaling almost US\$ 100 billion (IMS Healthcare, 2013) - it takes a company 1-10 US\$ billions and 10-15 years to create and launch a new drug (Glumskov, 2007). On the other one, it may be the socalled "geographical pool" that is more real state of things in the pharmaceutical market. More simply, it is corporations' conspiracy to deliver high-quality products mainly to countries with high purchasing power of the population in order to maximize profits.

In particular, the world's leading regions in pharmaceuticals production and consumption accounting for about $80 \%$ of the world's medicines market are the United States of America, countries of Western Europe and Japan (Figure 2). However, the pharmaceutical sales in the US, Canada, France, Germany, Italy, Spain, UK and Japan decreased by more than 2 times for the recent years. Against this background, new emerging pharmaceutical markets, such as India, Brazil, China, Korea, Turkey, Russia, Mexico, and Indonesia have been visibly growing (Ternovenko, 2010). It is expected that by 2015 the proportion of sales carried out in West-European and developing countries will be equal to $23 \%$ of the world's total sales (Figure 2).

For instance, Indian pharmaceutical industry is one of the most advanced in the world. According to the United Nations, in 2008 India got a position in "Top 15" ranking as one of the major medical products exporters with a share of 1.44\%. According to KPMG report, total expenditures including developing, registration and approval of an application of a new drug are on average 10\% of the similar costs in the US. Another explanation for the active growth of Indian pharmaceutical market may also be the global trends, such as aging of the population, and a transition to the prevalence cardiovascular and central nervous systems' diseases. India is expected to become one of the top 10 pharmaceutical markets with a volume of US $\$ 50$ billion (Ternovenko, 2010).

As for the other emerging markets, China may outrun India in a few years. Global corporations are highly interested in China because of both abrupt increasing of consumer demand (due to the same reasons as in India), and the possibility of low-budget outsourcing. Thus, according to Bain \& Company, about $90 \%$ of top-managers would prefer China than India when placing cheap drugs production. According to DSM Group report, annual increase of retail medicines market in China is about 14\%, which is 7 times higher than the average rate of $2.1 \%$. However, in this region structure of the industry and the degree of legal protection are still poorly developed. As a result, production costs for the more advanced stages in China (in particular, clinical trials) are comparable to those in the US and Europe (Industrial Review, 2008). Among the other most progressive pharmerging markets double-digit growth rates are also typical for national markets of Brazil (+ $17 \%$ in 2013), Venezuela (+32\% in 2010), Argentina (+26\% in 2010), Russia ( $+10 \%$ in 2013), Turkey, Indonesia and Korea (Ministry of Economic Development of the Russian Federation, 2012).

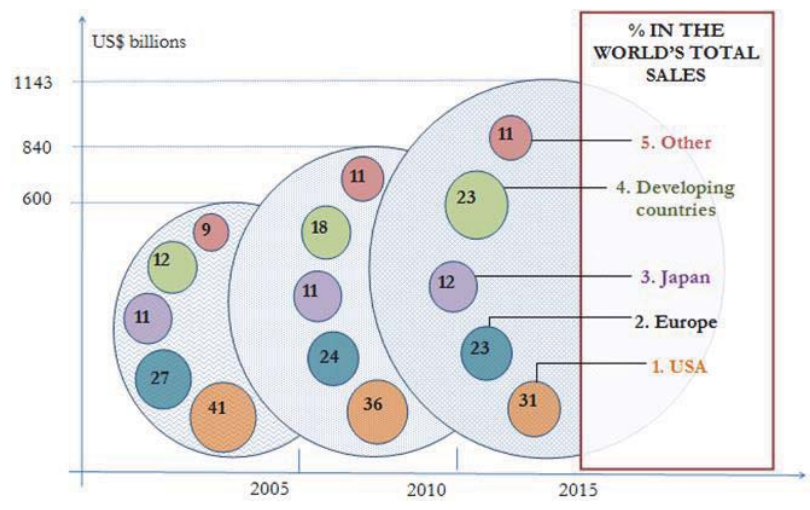

Figure 2. Pharmaceuticals sales by regions and countries 
Another questionable trend in the largest pharmaceutical companies' activity is policy of enforcement towards local companies. For example, in 2010 the Ukrainian divisions of the Franco-British Sanofi-Aventis were fined by antitrust authorities for mailing letters criticized the quality of Flenoks (Farmakom company), which was the direct copy-drug of Clexane made by Sanofi (Mikhailova, 2010).

\section{Methodology}

Current trends observed above prove that the global pharmaceutical market is the economy unit with an ambivalent nature. In this regard, we should question whether pharmaceutical market solves global health problems or only exists in order to maximize profits of the largest drug manufacturers? Herewith, the main goal of the study is searching for the answer by means of econometric analyzes (using IBM SPSS Statistics 19). In turn, the main hypothesis is the assumption of "geographical pool" existence with related negative consequences. By extension, the global pharmaceutical market operates in the interests of developed countries and enterprises hosted there. If so, we deal with another confirmation of the global economy uneven and unsustainable development.

Statistical databases of the World Bank, Organization for Economic Co-operation and Development, World Health Organization and information-analytical agencies in the field of health and pharmaceuticals (e.g., IMS Health) for 2011 were used in the study.

At the first stage it was presumed that the health services in developing (pharmerging) countries are on emerging stages so the public health is low. A spectrum of diseases common for developing countries was revealed mainly while studying the industry surveys. It involved infectious and chronic diseases, diabetes mellitus, tuberculosis, malaria and AIDS. In particular, accordingly to the experts of Eurasian Bank of Development, the number of people suffering from hypertension in developing countries reached the point of 639 million in 2004, but it is expected to be not less than 1 billion by 2025. In it's turn, the number of people with diabetes among India, the Middle East and Southeast Asia will increase from 84 million in 1995 up to 228 million in 2025 (Eurasian Development Bank, 2013). So, as a dependent variable (y) it was taken life expectancy at birth (in number of years). The independent variables (x) were GNI per capita (in US dollars); HIV prevalence (in \%); the incidence of tuberculosis, respiratory diseases and ischemic heart disease (in number of cases per 100000 persons). According to the analysis it was found out that:

1. Ischemic heart disease is the main constraint to the life expectancy growth in developed countries;

2. HIV infection and respiratory diseases are the main constraints to the life expectancy growth in developing countries (Nalimov, 2014).

Results of the analysis may be supported with the conclusion of PURE project, that included 155,245 people aged 35-70 years from 17 countries with high (Canada, Sweden, the United Arab Emirates, $n=16110)$, medium $(n=104,260)$ and low $(n=34875)$ economic level (India, Bangladesh, Pakistan, Zimbabwe). Accordingly to PURE, the highest prevalence of risk factors for cardiovascular disease was observed in the "rich countries", the lowest - in "poor countries". Meanwhile, heart failure were recorded at a frequency of 4.3, 5.1 and 6.4 per 1000 person-years, and the death from cardiovascular causes - 0.5, 1.3 and 2.7 per 1000 person-years in countries with high, medium and low economic level, respectively. "Rich countries" are notable for early detections and effective treatment of diseases, whereas "poor countries" characterized with poor development of health care system (Kanorsky and Mamedov, 2014).

It is necessary to realize that some diseases are important worldwide, being found in both poor and rich countries, and therapies for such diseases have global markets. Others are more specific, with almost their entire market in the developing world (for example, malaria). There is almost no investment in the latter category outside of the public sector.

Without protection in the developing world, there is little interest on the part of firms to invest in therapies for these diseases (Lanjouw, 2006). It means that success of treatment in most of the cases about specific diseases in developing countries depends on usage of low-budget medicines.

Herewith, according to the World Health Organization and The Global Fund experts, HIV infection, respiratory diseases, malaria and tuberculosis are the main "enemies" of the human health for today. They are ones due to the nature of their transmission (infectious nature and high seasonal influence (Holyman, 2005), while ischemic heart disease is acquired purely medical case. This means that the population of developing countries is objectively less healthy and less protected from infectious influence, and has less incomes and therefore it is in greater need of highly innovative drugs. 


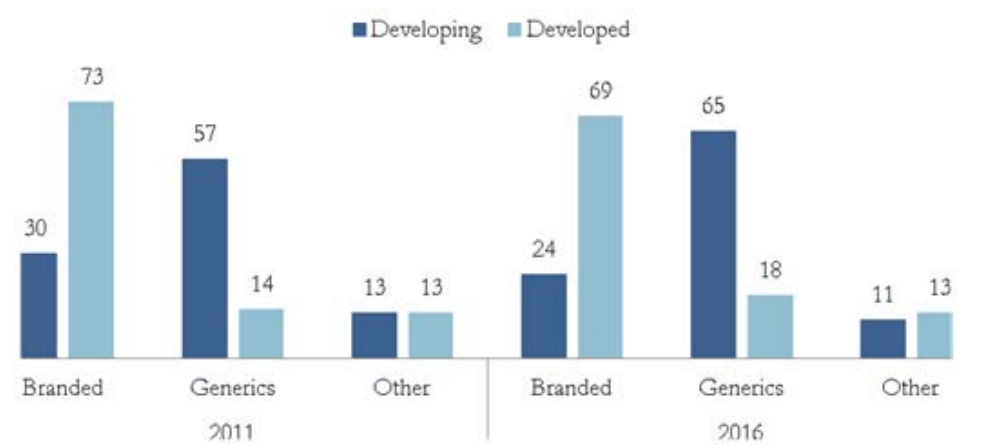

Figure 3. The worldwide structure of drugs consumption in 2011 and 2016

Paradoxically, but the fact is that the lion's share in effective branded drugs production and consumption retain the advanced economies, regardless of developing countries needs. Figure 3 indicates that the disproportionate medicine distribution has been mentioned above is not changing to its best in the nearest future. Developing countries will face the more complicated access to high quality medicines - ratio of branded drugs will decrease from 30\% in 2011 to $24 \%$ in 2016. In its turn, generics will be more available - we will observe the trend of low quality drugs growth - from $57 \%$ in 2011 to $65 \%$ in 2016 (IMS Healthcare, 2012).

It is important to make a rigid division between generics and brand drugs. So, branded drugs are innovations protected by patent law for 20 years or more. Generics are the drugs that reproduced after patent expiration (WHO Technical Report Series, 2005). It is important to note that the lack of health systems in developing countries is inadequate or frankly poor state regulation of drugs standardization and circulation. As a result, output of generic drugs does not require extensive pre-clinical testing and Good Manufacturing Practices (GMP) compliance. Moreover, a generic drug may be essentially different from a brand on the composition of excipients, releasing forms, pharmacokinetic parameters and the effectiveness of biotherapeutics (see Interstate Commission for Standardization, Registration and Quality Control of Drugs, Medical Devices and Medical Equipment of the Commonwealth of Independent States, 2013). Thus, the widespread use of generic drugs on the markets of developing countries may pose a serious threat to the health of the population.

In accordance with the hypothesis of the study at the second stage there were explored causes of such inequality by means of regression analysis (IBM SPSS Statistics 19). It was presumed that the causes of high generic drugs prevalence in developing countries are lack of research and development (R\&D) investment spent by local pharmaceutical companies, as well as the state medical care mechanism absence or its underdevelopment. In such situation, people in pharmerging countries have to cover all the costs for medical treatment by means of their own resource, not relying on a decent state aid.

A set of indicators characterizing research and development capacity, health potential, rates of mortality and effectiveness levels of national pharmaceutical industries was selected in order to conduct a comprehensive hypothesis testing. In this way, as a dependent variable ( $\mathrm{y}$ ) it was taken issued share of generic drugs. Independent variables ( $\mathrm{x}$ ) are given in Table 2 below.

Table 2. Used independent variables

\begin{tabular}{|ll|}
\hline VARIABLES & \\
\hline GNIpC & GNI per capita, USD \\
Ln-GNIpc & GNI per capita, logarithm \\
LIFE & Life expectancy at birth, years \\
SALE & Sales of pharmaceuticals per capita, US\$ \\
HEpc & Health expenditures per capita, US\$ \\
HE & Out-of-pocket health expenditures, \% of all health expenditures \\
PHEX & Export of pharmaceuticals per capita, US\$ \\
PHIM & Import of pharmaceuticals per capita, US\$ \\
GERD & R\&D expenditures, \% of GDP \\
HDI & Human Development Index \\
TUBER & Incidence of tuberculosis, number of cases per 100000 persons \\
RESP & Respiratory diseases, number of cases per 100000 persons \\
ISHMC & Ischemic heart disease, number of cases per 100000 persons \\
\hline
\end{tabular}




\section{Results}

The OLS regression model has shown that R\&D expenditures and GNI per capita have the greatest influence on share of generic drugs. The most significant variable (at the 5\%-level) is also life expectancy at birth. Less significant variables (at 10\%-level) are health expenditures per capita, export of pharmaceuticals per capita and number of ischemic heart disease cases per 100000 persons. The results of the carried econometric analysis are shown in the table 3.

Table 3. The results

\begin{tabular}{|c|c|c|c|c|c|c|}
\hline \multirow{2}{*}{ Regressors } & \multicolumn{6}{|c|}{ The share of generic drugs in the total drugs consumption (\%) } \\
\hline & (1) & (2) & (3) & (4) & (5) & (6) \\
\hline GNIpc & & & $\begin{array}{l}-, 001^{\star \star} \\
(, 000)\end{array}$ & $\begin{array}{l}-, 001^{\star \star \star} \\
(, 000)\end{array}$ & $\begin{array}{l}-, 001^{\star \star \star} \\
(, 000)\end{array}$ & \\
\hline Ln-GNIpc & $\begin{array}{c}-11,063^{\star} \\
(6,128)\end{array}$ & $\begin{array}{c}-8,427^{\star \star \star} \\
(1,473)\end{array}$ & & & & $\begin{array}{c}-7,787^{\star \star *} \\
(1,519)\end{array}$ \\
\hline LIFE & $\begin{array}{l}-, 194 \\
(, 54)\end{array}$ & & $\begin{array}{r}-, 029 \\
(, 513)\end{array}$ & & $\begin{array}{c}-, 534^{* *} \\
(, 253)\end{array}$ & \\
\hline SALE & $\begin{array}{r}-, 059 \\
(, 245)\end{array}$ & & $\begin{array}{r}-, 215 \\
(.243)\end{array}$ & & & \\
\hline HEpc & $\begin{array}{l}-, 003 \\
(, 01)\end{array}$ & & $\begin{array}{l}, 007 \\
(, 011)\end{array}$ & & & \\
\hline HE & $\begin{array}{l}-, 193 \\
(, 132)\end{array}$ & $\begin{array}{l}-, 199 * \star \\
(, 097)\end{array}$ & $\begin{array}{r}-, 200 \\
(, 128)\end{array}$ & $\begin{array}{l}-, 202^{\star *} \\
(, 098)\end{array}$ & $\begin{array}{l}-, 189 * \\
(, 101)\end{array}$ & \\
\hline PHEX & $\begin{array}{l}, 017 \\
(, 03)\end{array}$ & & $\begin{array}{l}, 019 \\
(, 029)\end{array}$ & & $\begin{array}{l}, 035^{\star} \\
(, 020)\end{array}$ & \\
\hline PHIM & $\begin{array}{l}-, 002 \\
(, 055)\end{array}$ & & $\begin{array}{l}, 017 \\
(, 054)\end{array}$ & & & \\
\hline GERD & $\begin{array}{l}-12,82^{* *} \\
(6,216)\end{array}$ & $\begin{array}{c}-10,187^{\star *} \\
(4,477)\end{array}$ & $\begin{array}{c}-13,832^{\star *} \\
(6,049)\end{array}$ & $\begin{array}{c}-9,480^{\star *} \\
(4,480)\end{array}$ & $\begin{array}{c}-15,983^{\star \star \star} \\
(4,995)\end{array}$ & $\begin{array}{c}-10,072^{\star *} \\
(4,437)\end{array}$ \\
\hline $\mathrm{HDI}$ & $\begin{array}{c}47,276 \\
(58,602)\end{array}$ & & $\begin{array}{l}-39,518 \\
(32,288)\end{array}$ & $\begin{array}{c}-44,335^{\star \star *} \\
(16,459)\end{array}$ & & \\
\hline TUBER & $\begin{array}{l}, 005 \\
(, 02)\end{array}$ & & $\begin{array}{l}, 003 \\
(, 019)\end{array}$ & & & $\begin{array}{l}, 020^{\star} \\
(011)\end{array}$ \\
\hline RESP & $\begin{array}{l}, 001 \\
(, 03)\end{array}$ & & $\begin{array}{l}-, 001 \\
(, 027)\end{array}$ & & & \\
\hline ISHMC & $\begin{array}{l}, 049^{*} \\
(, 028)\end{array}$ & $\begin{array}{l}, 057^{\star *} \\
(, 023)\end{array}$ & $\begin{array}{l}, 052^{*} \\
(, 029)\end{array}$ & $\begin{array}{l}, 051^{\star *} \\
(, 024)\end{array}$ & $\begin{array}{l}, 043^{*} \\
(022)\end{array}$ & $\begin{array}{l}, 040^{*} \\
(, 021)\end{array}$ \\
\hline Constant & $\begin{array}{c}154,2^{* * \star} \\
(34,6)\end{array}$ & $\begin{array}{c}148,237^{\star \star \star} \\
(12,617)\end{array}$ & $\begin{array}{c}114,045^{\star \star *} \\
(25,071)\end{array}$ & $\begin{array}{c}114,193^{\star \star *} \\
(10,143)\end{array}$ & $\begin{array}{c}124,824^{\star \star *} \\
(14,423)\end{array}$ & $\begin{array}{c}127,228^{\star * \star} \\
(12,883)\end{array}$ \\
\hline $\begin{array}{l}\text { Standard } \\
\text { regression error }\end{array}$ & 15,548 & 14,747 & 15,072 & 14,593 & 14,293 & 14,693 \\
\hline$R^{2}\left(\right.$ adjusted $\left.R^{2}\right)$ &, $525(, 421)$ & $\begin{array}{l}, 511 \\
(, 479)\end{array}$ & $\begin{array}{l}, 553 \\
(, 456)\end{array}$ & $\begin{array}{l}, 528 \\
(, 49)\end{array}$ & $\begin{array}{l}, 535 \\
(, 492)\end{array}$ & $\begin{array}{l}, 494 \\
(, 463)\end{array}$ \\
\hline $\mathrm{N}$ & 91 & 91 & 88 & 88 & 91 & 91 \\
\hline
\end{tabular}

An equation of the OLS regression model is given by (1):

$Y=-0.001$ GNIpc -0.534 LIFE -0.189 HE -15.983 GERD +0.035 PHEX +0.043 ISHMC

In accordance with the results of model 5 selected as the basis, share of generic drugs in pharmerging countries tends to increase when:

a. simultaneous increase in pharmaceutical exports and the rate of heart disease (direct dependence) are observed;

b. reducing life expectancy and the proportion of public expenditure spent on research and development, as well 
as reducing out-of-pocket health expenditures and GNI per capita (inverse dependence) are observed.

The results presented above enable us to come to a comprehensive conclusion.

First, negative consequences in predominance of generic drugs have been econometrically substantiated: the growth of inefficient medication increases the incidence of cardiovascular diseases, which ultimately has a negative impact on life expectancy.

Second, causes in dominance of generic drugs in the developing markets have been logically set. They are government inefficiency in creating incentives for innovative development of pharmaceuticals (It may be explained with low R\&D costs) and the low purchasing power of the population (due to the inverse dependence between $Y$ and GNI per capita).

And we also may see a paradox in production and consumption of pharmaceuticals among poor countries. It means that poorer countries in general contribute little to total world expenditure on drugs for global diseases, but at the same time can be a significant major source of demand in some therapy areas. According to Lanjouw (2006), about 46\% of the world's population is found in countries representing less than $2 \%$ of total expenditure on drugs, for example, for cardiovascular disease. It brings us to a conclusion about underdevelopment or even absence of national pharmaceutical industries among poorer countries. In this case, theirs huge need for medical drugs should be replenished by means of active pharmaceutical import.

However, the most interesting part of the results is the direct dependence between the ratio of generic drugs and the pharmaceutical export. This relationship may be explained by the narrow range of export and import in the scope of developing countries: mutual trade of pharmerging economies enhances the effect of low quality generic medicine. At the same time, it also means that the world leading corporations producing branded drugs ("Big Pharma") do not intentionally increase the share of innovative medicines in emerging markets (Lanjouw, 2006). There may be a rational explanation: being highly commercialized units of the world economy, they choose not to lose money - the main consumers in developing countries are moderate income households, which are opposed to the "rich" private and public sectors of developed countries. There may be another economically justified interest of developed countries - the lowest possible value of the imported goods and raw materials from developing countries. In this respect, advanced economies get the benefits from "the idle speed", not allowing pharmerging countries to grow by means of expensive human capital in the form of a healthy workforce (Rudenko and Tilimbaeva, 2013).

\section{Concluding Remarks}

Thus, extremely heterogeneous emerging markets, ranking at the moment about $20 \%$ of the market, are expected to become the "giants" that will determine the landscape of the global pharmaceuticals in the near future. The guarantee of this trend is their large enough market potential, further development of these markets in the context of health insurance implementation and household incomes. Players of the global pharmaceutical market, namely the largest pharmaceutical companies, are responding to this trend by increase of its presence and strengthening of its market positions.

As a mechanism of achieving a balance on the global pharmaceutical market should consist of some stages: 1. a consolidation of small national companies from developing countries into the regional pharmaceutical enterprises in order to R\&D concentration (stage 1); 2. patents buying up (stage 2); 3. the establishment of special customs and tax regimes for regionally produced medical drugs (stage 3).

Herewith, today's extremely uneven distribution of drugs between "rich" and "poor" countries does not yet allow us to speak about the importance of global health problems for all the world community. As a result, the study allows us to give an answer to the main question: the global pharmaceutical market is a system that contains all the resources for effective solving of global health problems. However, the existence of "Big Pharma" makes us talk about high commercial character of the global pharmaceutical market that is now prevailing over the idealistic notion about the healthy planet.

\section{Acknowledgement}

The study was supported by the Ministry of education and science of Russia, project 14.Z56.14.3051-MK.

\section{References}

Eurasian Development Bank (2013). Development Prospects for the Pharmaceutical Market of the Single Economic Space. Almaty. 38 p.<http://www.eabr.org/general//upload/docs/AU/\%D0\%90\%D0\%A3\%20-\%20\%D0\%98\%D0\%B7\%D0\%B4\%D0\%B0\% D0\%BD\%D0\%B8\%D1\%8F\%20-\%202013/OBZOR_18_engl_for_web.pdf> (accessed November, 2014). 
Financial Times (2014). FT Global 500. <http://www.ft.com/intl/indepth/ft500> (accessed November, 2014).

Glumskov, V. (2007). World Pharmaceutical Market: Status and Trends. Recipe Journal 54(4).

Hetman M. (2003). Big Pharma. Moscow: Litterra, 312.

Holyman. S. (2005). Tuberculosis and malaria. How healthy is your world? <http://www.who.int/features/2005/ health_survey/tb_malaria/ en/> (accessed November, 2014).

IFPMA (2013). The Pharmaceutical Industry and Global Health: Facts And Figures 2012. <http://www.ifpma.org/fileadmin/content/ Publication/2013/IFPMA_-_Facts_And_Figures_2012_LowResSinglePage.pdf> (accessed November, 2014).

IMS Healthcare (2013). The Global Use of Medicines: Outlook through 2017. <http://www.imshealth.com/deployedfiles /imshealth/Global/Content/Corporate/IMS\%20Health\%20Institute/Reports/Global_Use_of_Meds_Outlook_2017/IIHI_Global_Use of_Meds_Report_2013.pdf> (accessed November, 2014).

IMS Healthcare (2012). The Global Use of Medicines: Outlook Through 2016. <http://www.imshealth.com/deployedfiles/ims/ Global/Content/Insights/IMS\%20Institute\%20for\%20Healthcare\%20Informatics/Global\%20Use\%20of\%20Meds\%202011/Medicin es_Outlook_Through_2016_Report.pdf> (accessed November, 2014).

Industrial Review (2008). India and China: who will be the next pharmaceutical giant? <http://archive.promoboz.com/n6_11/32-35.pdf> (accessed November, 2014).

Interstate Commission for Standardization, Registration and Quality Control of Drugs, Medical Devices and Medical Equipment of the Commonwealth of Independent States (2013). The pharmaceutical industry and society: how many contradictions? $<$ http://pharm-cis.com/?id=1451> (accessed November, 2014).

Kanorsky, S.G., and Mamedov, M.N. (2014). Congress of European Society of Cardiology (Amsterdam 2013): New Recommendations and Most Important Clinical Studies. Kardiologia, 54 (5).

Lanjouw, J. (2006). A Patent Policy Proposal for Global Diseases. Innovations. Technology. Governance. Globalization. (1). 104-114. doi:10.1162/itgg.2006.1.1.108

Lin, A. and Sokolova, V. (2012). The pharmaceutical market: the fundamental features. Problems of nowadays economy 43(3), 372-375.

Mikhailova, E. (2010). Sanofi-Aventis paid for criticism. Pharmaceutical Bulletin. <http://www.pharmvestnik.ru/publs/staryj-arxivgazety/19654.htm|\#.UuAu3BAnrlV>

Ministry of Economic Development of the Russian Federation (2012). Position of the UK in pharmaceutical industry <http://www.ved.gov.ru/moder_innovac/prioritetnie_napravlenija/med_tehnika/mesto_velikobritanii_v_mirovoi_farmatsevtike/> (accessed November, 2014).

Nalimov, P. (2014). The ambivalence of global pharmaceutical market. Studies of young scientists: economic theory, sociology and regional economics. Collection of articles, 370-374.

Rudenko, D.Y., and Tilimbaeva, A.B. (2013). Investment in human capital and socio-economic development: relationship analysis and impact evaluation. Tyumen State University Herald, (11), 17-25.

Rudenko, D.Y. (2014). Alternative Approaches to Measure Poverty in Russian Regions. Mediterranean Journal of Social Sciences, 4 (13), 262-267. Doi:10.5901/mjss.2014.v5n13p262

Ternovenko, O. (2010). India Pharmaceuticals: strategy conquest of global leadership. Apteka.ua. <http://www.apteka.ua/article/50043> (accessed November, 2014).

WHO (2012). World Health Statistics. <http://www.who.int/gho/publications/world_health_statistics/2012/ru/> (accessed November, 2014).

WHO Technical Report Series (2005). Who expert committee on specifications for pharmaceutical preparations. <http://apps.who.int/prequal/info_general/documents/trs929/who_trs_929_annex5fdcs.pdf> (accessed November, 2014). 